\title{
Treatment of acute bronchiolitis with Chinese herbs
}

\author{
Xiao-Tang Kong, H T Fang, G Q Jiang, S Z Zhai, D L O’Connell, D R Brewster
}

\begin{abstract}
In a randomised single blind trial the Chinese herbs Shuang Huang Lian were evaluated for the treatment of acute bronchiolitis. Children with acute bronchiolitis and serological evidence of recent respiratory syncytial virus infection were studied in a tertiary hospital in Harbin, China. The 96 children were randomised into three treatment groups: herbs, herbs with antibiotics, and antibiotics alone. The herbs were prepared by the medical school pharmacy and administered daily by intravenous infusion for seven days. The main outcomes, assessed blindly, were symptomatic improvement in cough, fever, wheezing, chest signs, and duration of stay in hospital.
\end{abstract}

The mean duration of symptoms from the start of treatment was 6.2 (confidence interval 5.6 to 6.9) days in the two groups treated with herbs compared with 8.6 (confidence interval 7.5 to 9.8 ) days in the group treated with antibiotics alone. The mean reductions in duration of clinical manifestations for treatment with antibiotics alone compared with herbs were: from $3 \cdot 1$ to 1.5 days for fever, $9 \cdot 1$ to $6 \cdot 1$ days for cough, 6.5 to $4 \cdot 1$ days for wheezing, and 7.2 to 4.9 days for chest crackles. No adverse effect of Shuang Huang Lian herbal treatment was detected.

In conclusion, this study confirms Chinese experience with Shuang Huang Lian that it is safe and effective, and warrants further study. (Arch Dis Child 1993; 68: 468-471)

Acute bronchiolitis is the most common serious respiratory infection in infancy, affecting one in 50 infants annually in industrialised countries.' The respiratory syncytial virus is responsible for over $80 \%$ of hospital admissions, with a peak incidence during the winter months.

Respiratory syncytial virus bronchiolitis is also an important problem in the developing world. A group of studies from 10 developing countries on the epidemiology of acute respiratory infections reported that the children studied spent an average of $22-40 \%$ of observed weeks with signs of acute respiratory infection, and had incidence rates for lower respiratory tract disease ranging from $0 \cdot 2$ to $8 \cdot 1$ new episodes per 100 child weeks at risk, with the highest incidence in children less than 18 months of age. ${ }^{2}$ Although death rates for bacterial pneumonia are more than 50 times higher than for viral lower respiratory tract infections, the estimated number of deaths is only about $2 \cdot 7$ times higher for bacterial pneumonia. ${ }^{3}$ Respiratory syncytial virus is the most often identified agent in these studies, accounting for $15-20 \%$ of all viral pathogens, though mixed infections also occur. ${ }^{+6}$

Oxygen and nursing care are the mainstays of hospital management of acute bronchiolitis.
There is no evidence that bronchodilators, corticosteroids, or antibiotics improve the course of the illness. Tribavirin (ribavirin) administered by aerosol has been shown to be effective, ${ }^{7}$ but its administration is complex and its role in treatment of patients outside an intensive care unit is still unclear. Thus, a new effective treatment for acute bronchiolitis could offer considerable benefits.

Traditional Chinese herbal treatments have come under increasing scrutiny in recent years, with particular interest in qinghaosu for malaria, and various herbs for such diverse disorders as eczema, malignancy, and fertility control. Shuang Huang Lian is a combination of traditional Chinese herbs used to treat respiratory tract infections. Although there has been research into its effects, there have been no randomised clinical trials. The present study was undertaken to test the hypothesis that Shuang Huang Lian is a safe and effective treatment of acute bronchiolitis.

\section{Patients and methods}

The study was carried out at the First Hospital of the Harbin Medical School from 1988 to 1989. Harbin is a large inland city in the northeast of China at $46^{\circ} \mathrm{N}$ latitude (equivalent to Milan or Montreal). Children admitted to this hospital with lower respiratory tract disease and serological evidence of respiratory syncytial virus infection, excluding those with underlying diseases such as congenital heart disease, were included in the study. Informed consent was obtained from the parents of all children in the study. The study was approved by the ethics committee of the Bureau of Traditional Medicine in Harbin.

Of 215 patients with a clinical diagnosis of acute lower respiratory tract infection admitted during the study period, 110 had serological evidence of respiratory syncytial virus infection by $\operatorname{IgM}$ antibody capture assay combined with enzyme linked immunosorbent assay. ${ }^{8-12}$ Fourteen (13\%) children had to be excluded due to refused parental consent. The remaining 96 children were randomly assigned to one of three treatment groups: (a) group A was treated with Shuang Huang Lian herbs; (b) group B with Shuang Huang Lian herbs and antibiotics; and (c) group $\mathrm{C}$ with antibiotics alone (no herbs).

There were 32 children in group A, 34 in group $B$, and 30 in group $C$. The design was single blind, so the clinical investigator assessing signs and symptoms twice daily was not aware of the treatment. Clinical signs were assessed exclusively by the investigator, whereas symptoms such as coughing and wheezing also relied on reports from nurses and parents. Blood was taken on admission for full blood count, serology, and determination of immunoglobulins.
Australia

D L O'Connell

Dr Brewster.

Accepted 12 November 1992 
Table 1 Characteristics of the three groups before treatment

\begin{tabular}{|c|c|c|c|}
\hline & $\begin{array}{l}A \\
\text { (Shuang Huang } \\
\text { Lian) } \\
(n=32)\end{array}$ & $\begin{array}{l}B \\
\text { (Shuang Huang } \\
\text { Lian and } \\
\text { antibiotics) } \\
(n=34)\end{array}$ & $\begin{array}{l}C \\
\text { (antibiotics) } \\
(n=30)\end{array}$ \\
\hline $\begin{array}{l}\text { Sex }(M: F) \\
\text { Median (range) age (months) } \\
\text { Mean (range) symptom duration (days before }\end{array}$ & $\begin{array}{l}22: 10 \\
12(3-48)\end{array}$ & $\begin{array}{l}23: 11 \\
12(5-36)\end{array}$ & $\begin{array}{l}19: 11 \\
10(2-48)\end{array}$ \\
\hline $\begin{array}{l}\text { admission) } \\
\text { Severity of illness (mild:moderate:severe) }\end{array}$ & $\begin{array}{l}6 \cdot 4(1-20) \\
11: 15: 6\end{array}$ & $\begin{array}{l}5 \cdot 7(2-18) \\
12: 16: 6\end{array}$ & $\begin{array}{l}5 \cdot 8(2-15) \\
12: 13: 5\end{array}$ \\
\hline
\end{tabular}

${ }^{\star}$ From Bruhn and Yeager. ${ }^{15}$

Shuang Huang Lian consists mainly of the three Chinese herbs shuanghua, huangqin, and lianqiao, which are derived from plants. Shuanghua is the flower bud of Loniceya japonica, huangqin is the root of Scutellaria baicalensis, and lianqiao is the fruit of Forsythia suspensa. The herbs were prepared for clinical use by the pharmaceutical factory of the First Hospital of Harbin Medical School. ${ }^{13}{ }^{14}$ Shuang Huang Lian is received as a $20 \mathrm{ml}$ ampoule for intravenous infusion, which is diluted in $100-200 \mathrm{ml} 10 \%$ dextrose for administration. The dosage varies according to age $(20 \mathrm{ml}$ for patients under 6 months, $40 \mathrm{ml}$ for 7-36 months, and $60 \mathrm{ml}$ for patients over 36 months) and was administered over 30-60 minutes daily for seven days. The antibiotics used were either lincomycin $30 \mathrm{mg} /$ $\mathrm{kg} /$ day or cephazolin $100 \mathrm{mg} / \mathrm{kg} /$ day intravenously daily for seven days in a similar manner to the Shuang Huang Lian. Aspirin was administered symptomatically for fever over $38.5^{\circ} \mathrm{C}$, with no differences in use between the three treatment groups.

Odds ratios and $95 \%$ confidence intervals were calculated using the computer program Epi Info version 5 . The geometric mean durations of signs and symptoms with $95 \%$ confidence intervals were calculated after log transformation.

\section{Results}

On admission, all 96 children in the study group had coughing, $91 \%$ were wheezing, $86 \%$ had chest crackles, $80 \%$ had chest wheezes, and $53 \%$ had fever. Using a modified severity score, ${ }^{15} 35$ patients had mild disease, 44 moderate, and 17 severe. None of the patients required artificial ventilation, and there were no deaths. The median age of patients was 12 months; 22 were $0-6$ months and $59(61 \%)$ less than 12 months of age. As expected with respiratory syncytial virus infection in a hospital setting, there was a 2:1 male predominance and striking winter season-

Table 2 Mean duration (days) of signs and symptoms after treatment. Results given as geometric mean days ( $95 \%$ confidence intervals)

\begin{tabular}{|c|c|c|c|}
\hline Symptoms & $\begin{array}{l}A \\
\text { (Shuang Huang } \\
\text { Lian) }\end{array}$ & $\begin{array}{l}B \\
\text { (Shuang Huang } \\
\text { Lian and } \\
\text { antibiotics) }\end{array}$ & $\begin{array}{l}C \\
\text { (antibiotics) }\end{array}$ \\
\hline $\begin{array}{l}\text { Fever }(n=51) \\
\text { Cough }(n=96) \\
\text { Wheezing }(n=87) \\
\text { Chest wheezes }(n=77) \\
\text { Chest crackles }(n=83) \\
\text { Any sign or symptom }(n=96) \\
\text { Hospital stay }(n=96)\end{array}$ & $\begin{array}{l}1 \cdot 5(1 \cdot 2 \text { to } 2 \cdot 0) \\
6 \cdot 1(5 \cdot 3 \text { to } 6 \cdot 9) \\
4 \cdot 2(3 \cdot 7 \text { to } 4 \cdot 9) \\
4 \cdot 9(4 \cdot 0 \text { to } 5 \cdot 9) \\
4 \cdot 2(3 \cdot 5 \text { to } 5 \cdot 1) \\
6 \cdot 4(5 \cdot 6 \text { to } 7 \cdot 3) \\
7 \cdot 8(7 \cdot 0 \text { to } 8 \cdot 6)\end{array}$ & $\begin{array}{l}1 \cdot 9(1 \cdot 4 \text { to } 2 \cdot 5) \\
5 \cdot 5(4 \cdot 8 \text { to } 6 \cdot 3) \\
4 \cdot 0(3 \cdot 4 \text { to } 4 \cdot 6) \\
4 \cdot 6(3 \cdot 8 \text { to } 5 \cdot 6) \\
4 \cdot 3(3 \cdot 6 \text { to } 5 \cdot 2) \\
6 \cdot 0(5 \cdot 0 \text { to } 7 \cdot 1) \\
7 \cdot 0(6 \cdot 3 \text { to } 7 \cdot 8)\end{array}$ & $\begin{array}{l}2 \cdot 7(1.9 \text { to } 3 \cdot 8) \\
7 \cdot 7(6.7 \text { to } 8 \cdot 9) \\
6 \cdot 1(5 \cdot 2 \text { to } 7 \cdot 3) \\
7 \cdot 7(6.7 \text { to } 8 \cdot 9) \\
6.6(5 \cdot 6 \text { to } 7 \cdot 8) \\
8.6(7.5 \text { to } 9 \cdot 8) \\
9 \cdot 8(8.8 \text { to } 11 \cdot 0)\end{array}$ \\
\hline
\end{tabular}

$\mathrm{p}<0.01$ for groups $\mathrm{AB}$ combined $v \mathrm{C}$, except for fever.

Note: the discrepancy with the abstract data is due to non-geometric mean data. ality. There were no important differences between treatment groups on entry into the trial (table 1).

The course of the illness was significantly shorter in groups $\mathrm{A}$ and $\mathrm{B}$ than in group $\mathrm{C}$ (table 2). No significant differences were detected between groups $\mathrm{A}$ and $\mathrm{B}$, so they have been combined into the 'herbal' group with group $\mathrm{C}$ as 'non-herbal'. The mean duration of symptoms for herbal treatment was $6 \cdot 2$ (confidence interval 5.6 to 6.9 ) days compared with 8.6 (confidence interval 7.5-9.8) days in the non-herbal group. Furthermore, there were more children with an improvement in symptoms within two days of starting herbal treatment, and fewer with symptoms persisting for one week than in the nonherbal group (table 3). For example, after two days of treatment, patients treated with herbs were 4.0 times more likely to be coughing less and 13.2 times more likely to have an improvement in chest wheezes than the patients treated with antibiotics alone, and in the herbal patients it was only $0 \cdot 19$ and $0 \cdot 11$ times as likely for coughing and chest wheezes, respectively, to have persisted beyond seven days of treatment.

Chest radiographs were performed in 70 patients (73\%), and showed no abnormalities in 11 , hyperinflation in 12 , increased lung markings in 37 , and consolidation in 22 , with no significant differences between treatment groups. The mean (range) haemoglobin on admission in herbal treated patients (groups $\mathrm{A}$ and B) was $124 \mathrm{~g} / 1$ (95-165), with no abnormalities in white blood cell and differential counts. There were no significant differences in serum immunoglobulin concentrations in the acute phase or during convalescence between treatment groups, but overall IgM values were higher and IgG/IgA values lower than in controls without respiratory syncytial virus of the same age. No side effects or toxic reactions to Shuang Huang Lian were observed in the patients treated with herbs. Specifically, there was no pain or inflammation at the effusion site, no blood pressure changes during or immediately after the infusion, and no adverse effects on the children noted by parents or medical staff.

\section{Discussion}

Although Shuang Huang Lian is composed of three herbs, it has at least 29 known ingredients (table 4). Huangqin is known to enhance lymphocyte transformation and macrophage function, whereas lianqiao and shuanghua have antiinflammatory actions. The combination of herbs in Shuang Huang Lian has been shown in animal studies to be antipyretic, a stimulant of respiration and gut peristalsis, and a myocardial depressant. It has also in vitro inhibitory activity against certain bacteria and viruses (influenza, parainfluenza, and respiratory syncytial virus, but not adenovirus) as well as in vivo effects against influenza in mice. ${ }^{16}$ As our study groups $B$ and $C$ received wide spectrum antibiotics, bacterial inhibition does not explain the effect of Shuang Huang Lian in this study. The exact mechanism of Shuang Huang Lian action is unclear, however. We can only speculate about the relative contributions of anti-inflammatory, 
Table 3 Duration of clinical manifestations after treatment

\begin{tabular}{|c|c|c|c|}
\hline & $\begin{array}{l}\text { Herbal groups } \\
(A \text { and } B)(\%)\end{array}$ & $\begin{array}{l}\text { No herbs } \\
(C)(\%)\end{array}$ & $\begin{array}{l}\text { Odds ratio } \\
\text { (95\% confidence } \\
\text { intervals) }\end{array}$ \\
\hline \multicolumn{4}{|l|}{ Cough } \\
\hline $\begin{array}{l}\text { Improved by } 2 \text { days } \\
\text { Persisted more than } 7 \text { days }\end{array}$ & $\begin{array}{l}38 \\
20\end{array}$ & $\begin{array}{l}13 \\
57\end{array}$ & $\begin{array}{l}4 \cdot 0(1 \cdot 2 \text { to } 17 \cdot 2) \\
0 \cdot 19(0.07 \text { to } 0.53)\end{array}$ \\
\hline \multicolumn{4}{|l|}{ Wheeze } \\
\hline $\begin{array}{l}\text { Improved by } 2 \text { days } \\
\text { Persisted more than } 7 \text { days }\end{array}$ & $\begin{array}{r}56 \\
4\end{array}$ & $\begin{array}{l}17 \\
35\end{array}$ & $\begin{array}{l}6.4(2.0 \text { to } 23.6) \\
0.14(0.03 \text { to } 0.59)\end{array}$ \\
\hline \multicolumn{4}{|l|}{ Chest crackles } \\
\hline $\begin{array}{l}\text { Improved by } 2 \text { days } \\
\text { Persisted more than } 7 \text { days }\end{array}$ & $\begin{array}{l}47 \\
17\end{array}$ & $\begin{array}{l}20 \\
62\end{array}$ & $\begin{array}{l}3.5(1.2 \text { to } 11.9) \\
0.16(0.05 \text { to } 0.54)\end{array}$ \\
\hline \multicolumn{4}{|l|}{ Chest wheezes } \\
\hline $\begin{array}{l}\text { Improved by } 2 \text { days } \\
\text { Persisted more than } 7 \text { days }\end{array}$ & $\begin{array}{l}48 \\
15\end{array}$ & $\begin{array}{r}7 \\
62\end{array}$ & $\begin{array}{c}13 \cdot 2(2 \cdot 8 \text { to } 120.4) \\
0 \cdot 11(0.03 \text { to } 0.39)\end{array}$ \\
\hline
\end{tabular}

antiviral, immune enhancing, bronchodilator, or other unknown actions of Shuang Huang Lian. Further studies are needed to elucidate this question.

Shuang Huang Lian has been available as an intravenous preparation for the treatment of acute lower respiratory infections at the First Hospital in Harbin since 1973, and has been found to be clinically effective and free of toxic effects. This considerable clinical and laboratory experience with Shuang Huang Lian in China is not readily accessible in English, however. Xu Kai-Jian et al measured the bioavailability of baicalin (the major component of huangqin) and chlorogenic acid (the major component of shuanghua) in 14 adults after treatment with Shuang Huang Lian. ${ }^{17}$ After administration by mouth, peak serum concentrations of $4-6 \mu \mathrm{g} / \mathrm{ml}$ were reached at six hours, and levels of around $2 \mu \mathrm{g} / \mathrm{ml}$ for each component persisted for two to eight hours after intravenous infusion. The lethal dose $\left(\mathrm{LD}_{50}\right)$ of Shuang Huang Lian injection from animal studies is $56 \cdot 1(7 \cdot 1) \mathrm{ml} / \mathrm{kg}$.

There are some features of respiratory syncytial virus infection in these Chinese children which differ from the typical disease seen in paediatric wards in Western countries. We believe that these differences are real and not just related to patient selection or diagnostic criteria. At the First Hospital in Harbin, bronchiolitis is a less acute illness which affects a slightly older age group, and patients present later to hospital and have a more prolonged disease course. Thus, our non-herbal group had symptoms for a mean of 15 days, including six days before admission. A Beijing study found respiratory syncytial virus in $47(13 \%)$ of 364 acute respiratory admissions in children under 5 years, with 21 patients older than 12 months, and isolated adenoviruses from an additional $12 \%$ of patients with acute respiratory infection. ${ }^{18} \mathrm{~A}$ protracted clinical course of acute bronchiolitis has also been well documented in the UK. ${ }^{19}$

Table 4 Major known ingredients of Shuang Huang Lian herbs

\begin{tabular}{|c|c|c|}
\hline Shuanghua & Huangqin & Lianqiao \\
\hline $\begin{array}{l}\text { Chlorogenic acid } \\
\text { Isochlorogenic acid } \\
\text { Neochlorogenic acid } \\
\text { Lutedolia } \\
\text { Caffeoylquinio acid } \\
\text { Inositol } \\
\text { Linalool } \\
\text { Resin } \\
\text { Polysaccharide }\end{array}$ & $\begin{array}{l}\text { Baicalin } \\
\text { Baicalein } \\
\text { Neobaicalein } \\
\text { Wagonin } \\
\text { Wagonaside } \\
\text { B-Sitolerol } \\
\text { Anlylose } \\
\text { Oraxylin A } \\
\text { Skullcapflavone } \\
\text { Chrysin }\end{array}$ & $\begin{array}{l}\text { Forsythol } \\
\text { Rutin } \\
\text { Oleanolic acid } \\
\text { Forsythin } \\
\text { Volatile oil } \\
\text { Betulinic acid } \\
\text { Urgolic acid } \\
\text { Triterpenoid saponin } \\
\text { Cumarin } \\
\text { Alkaloid }\end{array}$ \\
\hline
\end{tabular}

There is still considerable confusion and controversy over the use of the terms bronchiolitis, bronchitis, and asthma. We attempted to circumvent this by restricting our study to children with confirmed respiratory syncytial virus infection, but unfortunately the IgM antibody capture assay combined with enzyme linked immunosorbent assay is not as reliable for respiratory syncytial virus as antigen tests (for example, immunofluorescence) or tissue culture. Although this test is highly sensitive for respiratory syncytial virus, it may remain positive for several months after acute infection, so that positive IgM serology could reflect past infection in some of our patients. Furthermore, some patients would have been diagnosed as having asthma in a Western hospital, as there was a previous history of wheezing in 10 of the 96 children (10\%). This could mean that Shuang Huang Lian benefits a wider spectrum of respiratory diseases than just respiratory syncytial virus infections. Nevertheless, the high prevalence of chest crackles and strong male predominance in our patients support respiratory syncytial virus bronchiolitis.

Finally, this was not a placebo controlled trial. Placebos were not considered acceptable in this cultural context, so intravenous antibiotic administration was used instead of a placebo in the non-herbal group and also in one of the groups treated with Shuang Huang Lian. Although ward staff and parents were not specifically blind to the study, the protocol for intravenous antibiotic treatment was similar to the herbal administration as once daily intravenous administration. The use of antibiotics as placebo could introduce a potential bias, as two studies have found antibiotics to be possibly detrimental in respiratory syncytial virus bronchiolitis. ${ }^{2021}$ Our study design with three groups enables us to exclude this, however, as we found no differences between the groups treated with herbs and antibiotics (group B) and herbal only group (group A) (table 2).

In conclusion, the results of this study support the clinical experience with Shuang Huang Lian in the treatment acute bronchiolitis in China and show that it is safe and shortens the clinical course of the illness. We believe that the reductions in duration of symptoms in the patients treated with Shuang Huang Lian (tables 2 and 3) are clinically significant. Although the administration of Shuang Huang Lian intravenously in this study indicates its pharmacological potency, this method of treatment for seven days would limit its usefulness in a Western context where admission to hospital for bronchiolitis may last only a few days. Consequently, one of us (Kong) is currently studying its administration as a nebulised solution, and preliminary results from Beijing Children's Hospital suggest that it is equally effective by this route. We believe that this warrants further study.

The authors thank Dr Thomas Stapleton of Lane End, High Wycombe, for his support and encouragement.

1 Phelan PD, Landau LI, Olinsky A. Respiratory illness in children. 3rd Ed. Oxford: Blackwell Scientific, 1990 
2 BOSTID Researchers. The epidemiology of acute respiratory tract infection in young children: comparison of findings from several developing countries. Rev Infect Dis 1990; 12 (suppl 8): S870-88.

3 Berman S. Epidemiology of acute respiratory infections in children of developing countries. Rev Infect Dis 1991; 13 (suppl 6): S454-62.

4 Ghafoor A, Nomani NK, Ishak Z, et al. Diagnoses of acute lower respiratory tract infections in children in Rawalpindi and Islamabad, Pakistan. Rev Infect Dis 1990; 12 (suppl 8): S907-14.

5 Korppi M, Leinonen M, Koskela M, Makela PH, Launiala K. Bacterial coinfection in children hospitalized with respiratory syncytial virus infections. Pediatr Infect Dis $\mathcal{F}$ 1989; 8 687-92.

6 Hietala J, Uhari M, Tuokki H, Leinonen M. Mixed bacterial and viral infections are common in children. Pediatr Infect Dis F 1989; 8: 683-6.

7 Smith DW, Frankel LR, Mathers LH, Tang AT, Ariagno RL, Prober CG. A controlled trial of aerosolized ribavirin in infants receiving mechanical ventilation for severe respiratory syncytial virus infection. N Englf Med 1991; 325:24-9.

8 Kong Xiao-Tang, Fang HT. Rapid diagnosis of respiratory syncytial virus infection by IgM antibody capture assay. fournal of Harbin Medical University 1989; 23: 172

9 Meurman O, Sarkkinen H, Ruuskanen O, Hanninen $P$, Halonen P. Immunoglobulin class-specific antibody response in RSV infection measured by enzyme immunoassay. F Med Virol 1984; 14: 67-72.

10 Hornsleth A, Friis B, Grauballe PC, Krasilnikof PA. Detection by ELISA of IgA and IgM antibodies in serum in primary lower RSV infection. F Med Virol 1984; 13: 149-61.
Sutherland S, Briggs JD. The detection of antibodies to CMV in the sera of renal transplant patients by $\operatorname{IgM}$ antibody capture assay. 7 Med Virol 1983; 11: 147-59.

12 Shen-Sheng L, Hong J, Fang HG. Rapid diagnosis of RSV infection: application of IgM antibody capture assay. Shangai: infection: application of IgM antibody capture assay. Shangai: Research [in Chinese].

13 Wu BJ, Huang WX, Yu CP, Zhou XB, Zhang SL, Yang RQ. Pharmacology of Chinese herbs. Beijing: People's Health Publication Corporation, 1983.

14 Jiang MX, Yang ZC, Yie YW, Zhang PR, Jing JZ, Shun JJ. Pharmacology. 2nd Ed. Beijing: People's Health Publication Corporation, 1984: 398

15 Bruhn FW, Yeager AS. Respiratory syncytial virus in early infancy: circulating antibody and the severity of infection. Am 7 Dis Child 1977; 131: 145-8.

16 Zhang XL, Zhang ZL, Chen RZ. Laboratory research on the effect of Shuanghuanglian injection on respiratory syncytial virus. Chinese foumal of Microorganism Immunology 1988; 8: virus.

$17 \mathrm{Xu} \mathrm{KJ}$, Yang XH, Hu JR, Lu YC, Zhang HJ. Research on Chinese Herbal Medicine 1987; 2: 1 .

18 Zhang Z, Wang Z, Cao Y, Zhu Z, Liu Y, Lin L. Acute respiratory infections in childhood in Beijing: an etiological study of pneumonia and bronchiolitis. Chin Med $\mathcal{F}[E n g l]$ 1986; 99: 695-702.

19 Heycock JB, Noble TC. 1,230 cases of acute bronchiolitis in infancy, $B M 7$ 1962; ii: 879-81.

20 Hall CB, Powell KP, Schnabel KC, Gala CL, Pincus PH. Risk of secondary bacterial infection in infants hospitalized with respiratory syncytial viral infection. $\mathcal{F}$ Pediatr 1988; 113: 266-71.

21 Arimasu $\mathrm{O}$. Clinical studies on the secondary bacterial infection in RSV infection in children. Kansenshogaku-Zash 1989; 63: 248-55. 